Prinzipien zu reduzieren auf die Zustimmung der Basis zu den Projekten und Entscheidungen, die von oben kommen, so daß das anfängliche Entscheidungsverfahren umgekehrt wird.

Der Rezensent stimmt aufgrund seiner langjährigen Erfahrungen in Algerien, gerade in der entscheidenden Phase der Ausarbeitung der Nationalcharta und der Verfassung von 1976, mit den vorstehenden Folgerungen Bensalahs weitgehend überein, die er übrigens noch nicht kannte, als er die obige Besprechung zum Buch von Baumann schrieb.

Der volle Wortlaut der Verfassung vom 19. 9. 1976 mit der Ergänzung vom 7. 7. 1979 sowie eine Chronologie von 1962-1979 vervollständigen das empfehlenswerte Buch.

Gerhard Moltmann

\title{
Maxime Rodinson
}

\section{Les Arabes}

2. Aufl., Presses Universitaires de France, Paris, 1979, 175 S.

Der Verfasser beschäftigt sich seit rund einem halben Jahrhundert mit der arabischen Welt, dem Volk und seiner Kultur. Das vorliegende Werk geht kaum über das Format eines Taschenbuches hinaus, informiert aber ins Detail gehend auch den Leser, der sich erstmals diesem Themenkreis zuwendet.

Im ersten Teil seines Buches formt der Verfasser den Titel zu der Frage um "Wer sind die Araber?" und bemüht sich, durch verschiedene Abgrenzungskriterien (gemeinsame Sprache, gemeinsames kulturelles Erbe, islamischer Glaube) eine bef riedigende Antwort $\mathrm{zu}$ finden. Arabischer Volkszugehörigkeit - wobei dieser Begriff nicht deckungsgleich mit dem der Ethnologen verwandt wird - sind diejenigen, welche die arabische Sprache oder eine ihrer Varianten sprechen und diese Sprache als ihre Muttersprache betrachten, die Geschichte und kulturelle Wurzeln einschließlich der seit dem 7. Jh. existierenden islamischen Religion als gemeinsame Heimat empfinden und die darüberhinaus das Bewußtsein arabischer Nationalität besitzen (der Verfasser nennt es "arabité").

Geographisch wird der arabische. Kulturkreis - und mithin die Bevölkerung, die das Bewußtsein arabischer Nationalität besitzt - auf bestimmte Gebiete eingeengt: die arabische Halbinsel (politisch im wesentlichen Saudi-Arabien), das Gebiet des "Fruchtbaren Halbmonds" sowie Ägypten und dann die Randzonen Sudan, Mauretanien und Nordaf rika. Der Verfasser gibt einen summarischen Einblick in die geschichtliche Entwicklung dieser Gebiete und berücksichtigt insbesondere die sukzessive Arabisierung der dort ansässigen Bevölkerung. Vor allem im Gebiet des "Fruchtbaren Halbmonds" fällt die Ablösung und/oder Uberlagerung verschiedener Kulturen auf: die Verdrängung des Akkadischen, Phönizischen und Hebräischen durch das Aramäische, die Einführung der griechischen Sprache als Sprache einer intellektuellen und wirtschaftlichen Oberschicht und schließlich - mit der muslimischen Eroberung - die Einführung des Arabischen als Ver- 
waltungs- und später auch als Umgangssprache der inzwischen arabisierten und islamisierten Bevölkerung.

Dem arabischen Nationalismus, seinen Ursprüngen und seiner geistesgeschichtlichen Entwicklung widmet der Verfasser das 3. Kapitel seines Buches, um dann eine Prognose über die Zukunftschancen einer einigen arabischen Welt in Form eines supranationalen, alle Muslims vereinenden Dár al-Islám zu stellen. Die Realisierung eines solchen einheitlichen arabisch-islamischen Staatsgebildes hat Politiker wie Philosophen seit jeher bewegt, der schöne Traum ist jedoch bisher über schwache Anfänge in der Verwirklichung nicht herausgekommen. Der Verfasser zeigt unter Abwägung der kulturellen und wirtschaftlichen Gegebenheiten der heutigen Zeit die realistischen Möglichkeiten auf, einer weiteren Zersplitterung der arabischen Welt entgegenzuwirken. Seine Schrift kann auf Grund ihres summarischen Charakters das Thema nicht erschöpfend behandeln, deutet jedoch Widerstände und Lösungsmöglichkeiten für eine Einigung an. Dem interessierten Leser bieten Quellenangaben und zahlreiche Fußnoten Gelegenheit zur Vertiefung und weiteren Erforschung der oftmals nur angedeuteten Probleme.

Dagmar Hohberger

\section{B. Miller (ed.)}

\section{Peasants and Politics - Grass Roots Reactions to Change in Asia}

St. Martin's Press, New York 1978, 218 S.

Six authors have contributed to an important issue, viz. how the masses of Asian "peasants" have acted and reacted to external oppression and exploitation at different instances of their history. Reactions differ, and so the papers dealing partly with older, partly with more recent events differ in approach and content.

Already the two contributions about communist countries are widely apart. The difficult and changing relationship between the Vietnamese peasantry and the communist party are lucidly analyzed by Christine Pelzer White. Revolutionary marxist leaders of nonpeasant origin are the only ones able to organize the poor peasants and lead them to victory; but later on, in land distribution, collectivization, taxation of the beneficiaries several problems arise, that ask for new sensitive decisions, where many political mistakes are possible and are made. Also, marxist social analysis, though generally very valuable and valid, does not easily fit intricate rural reality and match peasant social class consciousness. - Neville Maxwell deals with one particular aspect of China's rural transformation, the Learn - from-Tachai-movement. The paper seems outdated af ter the revelations about this "movement ", initiated from above, highly subsidized by the government, with doubtful achievements, never to be reached by normal working units. It had its parallels in Russian "movements" of the 30's to 50's, now largely forgotten. Such development demagoguery should have been viewed and reviewed more coolly, particularly by 